\title{
Transitional Justice in South Africa
}

\author{
Sethulego Matebesi
}

\section{Introduction}

Ever since the release of Nelson Mandela on 11 February 1990, South Africa has undergone multiple transformations. The primary and perhaps most challenging one was to address the legacies of an unjust past punctured by racial division. As was the case with many African countries, South Africa attempted to address past human rights abuses through several policy reforms such as the South African Truth and Reconciliation Commission (TRC). However, the overall approach toward addressing the violent and painful past into a stable and peaceful South Africa democratic state is somewhat murky. The consequence is that decades after the demise of apartheid, South Africans are still yearning for the so-called rainbow nation with minor trauma.

Internationally, the United Nations has played a significant role in setting standards for transitional justice efforts. In this regard, the United Nations supports nationally determined transitional justice initiatives. Still, in turn, it expects nation-states to conform to the growing body of international standards it has set (Grover, 2019). Globally, diverse interventions and complex and contested contexts that include, for example, truth commissions, reparations, and memorialization, characterize transitional justice (Waterhouse, 2009; Hayner, 2011; see also Figari Layús' contribution in this volume). While transitional justice goals at the state level are often framed to encompass outcomes such as reconciliation and peacebuilding (Duggan, 2012), there is a need to balance principles and pragmatism. Gready and Robin (2020) aptly note that addressing the past in transitions from conflict or repressive rule includes different mechanisms or approaches. However, constructing peace and ensuring justice have been criticized for being exclusive alternatives, as maintenance of peace often proceeded justice (Ramsbotham et al., 2011).

Notwithstanding significant progress in transitional justice efforts globally, South Africa's TRC offers ample examples of how a restorative approach can be implemented for nations to forgive and reconcile after periods of injustice. The TRC moved away from retribution by focusing on 
reparation, compensation and reconciliation, before actual reintegration programmes (Walaza, 2003; Bubenzer, 2014; Aiken, 2016). As a result, the TRC in South Africa played a critical role in advancing transformation in the country. For this and many other reasons, the country's TRCs are globally regarded as exemplary (Christodoulidis, 2000; Moon, 2009).

Against this background, the chapter examines the role of citizen participation and political trust in the context of transitional justice in South Africa, assesses the interaction of these phenomena, and reviews the literature on civil society mobilization for a just society as well as current perceptions about reconciliation efforts. Primarily, the focus is on how citizen participation and political trust shape perceptions of transitional justice efforts. I argue that stakeholders need renewed attention and action to embody a sustainable memory culture in contemporary South Africa. Besides, this suggests a restorative justice pathway that emphasizes inclusion and participation as instruments to engender trust in the processes aimed at healing past atrocities.

\section{Intersection of Social Justice, Political Trust, and Participatory Processes}

There is considerable variation worldwide in the legal status of restorative justice processes in transitional societies, with some programmes enshrined in law and others having no formal legal status. The latter relates to Pakistan's peacemaking processes, the Middle East, and the community-based mediation programmes in Guatemala (Jakobsson, 2018). Most transitional justice research in South Africa focuses on disarming, demobilizing and reintegrating ex-combatants. The research further focused on creating a new defence force that consists of different military structures (van der Merwe \& Lamb, 2009). The TRC found that the state perpetrated several gross human rights violations in South Africa and other Southern African countries (Swaziland and Zimbabwe). These violations include torture, abduction, severe mistreatment, sexual assault, unjustified use of deadly force etc. (TRC, 1998). Therefore, it is necessary to consider the role of trust and citizen participation in the transitional justice efforts in South Africa.

Political trust is seen as the structural component of social capital (Bains \& Hicks, 1998) and a direct consequence of institutional performance (Krisna \& Shrader, 2000). It is based on the political circumstances in which citizens find themselves at a given time (Gormley-Heenan \& Devine, 2010). The national contexts, including its institutional organization, policy, and socioeconomic conditions, influence people's cognitive 
ability to assess their circumstances (Krishna \& Shrader, 2000). Duckitt and Phuting (1998) argue that perceptions of and outrage about intergroup socioeconomic inequality and deprivation dominate the attitude of the oppressed towards its erstwhile oppressor. In this regard, reconciliation is a complex set of processes of rebuilding relationships in the aftermath of human rights violations. In the absence of trust at the individual, interpersonal, socio-political, and institutional levels, these relationships can be described as thin reconciliation. Thick reconciliation is when relationships are based on dignity restoration through trust, respect, and shared values, reversing structures (Seils, 2017).

For both reconciliation and transitional justice, trust is a critical factor shaping the processes and their aims. As governments and public institutions play a fundamental role in supporting inclusive societies, their performance and expectations influence the level of trust and citizens' experience in decision-making (Matebesi, 2017). Thus, the erosion of trust in government poses severe consequences for the quality and ability of representative democracy, its institutions, and its actors (van der Meer, 2017). In this regard, Hardin (2002) argues that newly built institutions can weather citizen distrust of the government.

Citizen participation is a critical factor that can enhance trust in institutions and transitional justice processes. A key part of citizen participation is to involve people who have experienced periods of conflict and human rights violations and the prime beneficiaries of transitional justice strategies (Shaw \& Waldorf, 2010). In this regard, Triponel and Pearson make a valuable contribution when they contend:

"Maintenance of peace in the long term in post-conflict society depends on a number of factors. In particular, the objectives of transitional justice can only be met if the population demonstrates ownership of the structures that are established. Countries can achieve this ownership by building meaningful consultation into the transitional justice mechanisms at the outset" (Triponel \& Pearson 2010: 103).

Therefore, unlike state-driven or top-down approaches (McEvoy, 2008), involving citizens in designing and implementing transitional justice strategies creates opportunities for a bottom-up approach. This form of participation indirectly addresses the marginalization and disempowerment that are the root causes of human rights violations. In this way, citizen participation in transitional justice processes enhances the self-esteem and confidence of victims (Laplante \& Rivera Holguin, 2006). Citizens are also more likely to support initiatives they were actively involved in from the outset (Laplante, 2013). Some scholars argue that transitional justice is a 
process embedded in power yet highly depoliticized (McEvoy, 2008; Millar $\&$ Lecy, 2016). However, others have also warned that both top-down and bottom-up approaches can potentially ignore, neglect and undermine local agencies as they depoliticize both the conflict they seek to address and the peace they intend to build (Triponel \& Pearson, 2010; Laplante, 2013; Charbonneau \& Parent, 2013).

Specific reconciliation policies or activities promote reconciliation through various processes in transitional societies. In this regard, citizen participation in transitional justice is crucial. The need for transitional justice initiatives to be perceived as legitimate by citizens cannot be overemphasized. They have to participate in transitional justice institutions and accept their decisions. When viewed as illegitimate and biased, transitional justice efforts can foster division instead of overcoming them. Participation can provide avenues for the voices of victims in the design of transitional justice strategies. This will more likely make the strategies responsive to local priorities (Selim, 2014). The degree of citizen participation in the varying transitional justice mechanisms is dependent on the type of transitional justice system being implemented (Triponel \& Pearson, 2010). Scholars have also found that when transitional justice is imposed internationally, it creates gaps with local citizens and affects its legitimacy. This gap widens further if the government and other leading stakeholders in the transitional process do not understand what victims need and ultimately deliver (Shaw \& Waldorf, 2010).

Bosire (2006) cautions that transitional justice is typically understood within the legal framework of state responsibilities. Therefore, transitional justice measures primarily seek to establish or restore trust between the state and citizens who conform to specific parameters. However, 'the unmet expectations of transitional justice efforts are partly due to a default resort to a legally and institutionally demanding understanding of transitional justice that is not congruent with the quality and capacity of state institutions in times of transition' (Bosire, 2006: 31). I now turn to transitional justice processes in South Africa.

\section{Transitional Justice Process: the South African Experience}

According to Laplante, "truth commissions often elaborate very general, and often overly ambitious, reparation plans to provide an effective remedy to human rights victims" (2013: 222). This section focuses on trust and citizen participation in transitional justice processes in South Africa. 
It is historically widely known that South Africa was characterized by violence and institutionalized racial discrimination (Aiken, 2016). White South Africans generally enjoyed a disproportionate share of resources under a system, which was enforced with brutal violence, shame and humiliation. After nearly five decades of this cruel system, South Africa made a peaceful transition to a more democratically elected government in 1994 (Kunnen, 2018). The negotiated Constitution of South Africa received broad support, with its provisions widely accepted by political parties and citizens. A central feature of the negotiations for liberation parties and the government was amnesty for past human rights abuses. This provision was a significant victory for human rights campaigners (van der Merwe \& Lamb, 2009). For example, while Amnesty International and Human Rights Watch were opposed in principle to granting amnesty for gross human rights violations, they were satisfied with the conditionality and specificity of the TRC's amnesty process. These included allowing survivors or relatives of human rights abuses to oppose amnesty applications, extensive investigations and cross-examination of the applicants. The human rights organizations also welcomed the decision to individualize amnesty applications instead of granting blanket amnesties for political organization parties (Bowsher, 2020).

Despite several challenges facing the TRC, including criticism for producing truth far from truth (Gibson, 2005), the Commission played a central role in managing racial conflicts and state-sponsored and state-supported crimes against the Black majority. Furthermore, the nonviolent approach adopted by the TRC was instrumental in engendering the tacit principle of Ubuntu (the African philosophy of humanism) (Vora \& Vora, 2004) introduced by the TRC Chairperson. The Ubuntu principle promotes values of empathy, forgiveness, and sharing in a conscious effort to resolve common problems. This enabled South Africa "to transform the conflict situation largely to harmony and reminded the groups of their shared unity" (Arthur et al., 2015: 75).

At the TRC hearings, the focus was on the victims and their families. As a result, for many victims of apartheid, testifying before the TRC was a transformative experience. The TRC offered amnesty for individuals under specific conditions. Perpetrators had to fully confess their crimes and had to show that their crimes had been politically, not personally, motivated. Despite some flaws, the TRC was a successful form of restorative justice as it sought to promote the acceptance of responsibility on the part of offenders to acknowledge the harm suffered by victims, and the victims aim of healing and restoration for all concerned (Department of Justice and Constitutional Development, 2011). 
Closely linked to transitional justice processes in South Africa were the issues of reparation and prosecutions. For instance, the philosophy of restorative justice rose to respond to the need for changes in the country's punitive criminal justice system. This was to accommodate indigenous African legal practices, which are more participatory and reconciliatory (Joyce, 2006). Van Zyl argues that the "TRC represents a 'third way' in dealing with past human rights abuse and attempting to institutionalize justice" (1999: 648). In this regard, the TRC followed a middle path by insisting on the prosecution, acceptance of amnesty and impunity. South Africa has a relatively well-developed and modern criminal justice system that draws its roots from a blend of Roman-Dutch and English law. In addition, it has, over the years, drawn and borrowed from a variety of respected international legal systems. Generally, though, the foundation upon which the South African criminal justice system rests was designed to provide a human rights system either not previously available to all citizens or not entrenched in law (Downes et al., 2016).

\section{Reparations and Local Transitional Justice Initiatives}

The TRC was not the only tool of transitional justice in South Africa. Others included were reparations, institutional reform, and local transitional justice initiatives. Regarding reparations, the TRC mandated its Reparations and Rehabilitation Committee to design a policy of how best to assist the victims. These victims included direct survivors, family members and/or dependents of someone who had suffered a politically motivated gross violation of human rights (Hamber, 2000). A significant challenge for the TRC was to deal with a myriad of reparation strategies which ranged from monetary (compensation payment) or symbolic reparations (for example, building memorials and renaming public facilities) (TRC, 1998).

While victims only began to receive reparations in 2003, perpetrators benefited immediately from the amnesty process. As a result, the TRC was heavily criticized for failing to advance the victims' interests in comparison to the perpetrators', including defining the concept of victims too narrowly. Again, victims of human rights abuses could not pursue civil claims against perpetrators who were granted amnesty (Hamber \& Kibble, 1999; van der Merwe \& Lamb, 2009). The TRC also understood the need to ensure that reparations become visible, directed, and individualized, but it focused only on gross violations. Thus, social reconstruction as a form of reparation, for example, providing better access to health care and 
development, was to take place in addition to and not to the exclusion of individualized reparations or collective reparation strategies (Hamber, 2000).

International literature on local transitional justice initiatives highlights that local ownership —as a form of community engagement and empowerment-is a significant currency in post-conflict societies. The literature argues that the most effective transitional justice interventions emerge from the locals (McEvoy, 2008; Bell, 2009; Lambourne, 2009; Jakobsson, 2018; Grover, 2018). Peace processes and justice mechanisms not embraced by those who have to live with them are unlikely to be successful if they are perceived as being imposed by external actors. This may create resentment that undermines both the legitimacy and effectiveness of transitional justice processes (van der Merwe \& Lamb, 2009).

In trying to effect these principles, various local justice and reconciliation initiatives were developed in South Africa. These initiatives included, for example, processes of local community healing meetings, disappearance support and investigation programs, restorative justice dialogues, victim counseling programs, survivor advocacy initiatives, memorialization projects and ex-combatant reintegration programs. Some of these initiatives, such as restorative justice dialogues, enabled ex-combatants to engage directly with victims, affecting collaboration in developing local community memorialization initiatives. The restorative justice dialogues enabled ex-combatants to engage directly with victims. This increased collaboration in developing local community memorialization initiatives (Greenbaum, 2006).

\section{Institutionalization of Transitional Justice Measures in South Africa}

The history of transitional justice shows that its high degree of institutionalization in countries in the Southern Cone of Latin America, Central and Eastern Europe, and South Africa has aided its efforts to deal with the human rights abuses of the past. Institutions regulated by laws in these countries ensured interactions between citizens and the state. Transitional justice measures included a significant dimension of institution-building to respond to the context and to strengthen civil society in advocating for truth, justice, reparation and non-recurrence (Special Rapoteur, 2017). While transitional justice has contributed to the entrenchment of rights to justice, truth and reparation, and to their operationalization, there are limitations to the institutions' achievement of even the narrowest goals. Thus institutions may reinforce ownership of the process by the state and 
elites (Robins, 2017). Conversely, poor institutionalization causes underperformance of transitional justice measures. For example, in conditions with few legitimate rules and institutions, transitional justice prosecutions and vetting programs can clash with the informal state's patronage logic (van der Merwe \& Lamb, 2009).

Internationally, efforts to further develop norms and standards to address human rights violations contributed to the legalization and codification of international criminal law, international humanitarian law and human rights law by special bodies (Bell, 2009; Subotić, 2009). For instance, in 1993 and 1994, the International Criminal Tribunal for the former Yugoslavia (ICTY) and the International Criminal Tribunal for Rwanda (ICTR) were established. The expansion of transitional justice institutionalization found further expression in the International Criminal Court (ICC), established in 1998. The ICC was created to investigate and try individuals charged with the world's gravest crimes of concern to the international community. This expansion of the institutionalization of transitional justice efforts enabled its mainstreaming, thereby strengthening accountability for past crimes and the struggle against impunity in post-conflict societies (Rubli, 2012).

In the South African context, violations' conditions and historical context demanded a comprehensive and more substantive conception of transitional justice that went beyond juridical and legal forms of justice. For the TRC to encourage participation and support testimony from those directly involved with the issues under investigation, processes and structures needed to be in place to protect both the victims and perpetrators from the dangers of participation. In this regard, the Commission of Inquiry for the Prevention of Public Violence and Intimidation, popularly known as the Goldstone Commission, played a central role in, among others, transforming information gathering measures and the institutionalization of witness protection in South Africa. The Goldstone Commission is a precursor to the legislative framework and institutionalization of TRC processes in South Africa (Lambert, 2020). A notable feature of the Goldstone Commission-specifically with the Prevention of Public Violence and Intimidation Act-was its power to search and seize documents, and thus move beyond voluntary witness testimony in gathering evidence for its investigations (Government of South Africa, 1992)

Later, the South African TRC would benefit from the operation of the Goldstone Commission in terms of investigative credibility and institutional experience. The Commission's work helped strengthen information gathering during the negotiating period in South Africa and facilitated further change in information-gathering capacities, including institutional- 
izing witness protection in South Africa (Lambert, 2020; Newham, 2015). Lambert notes:

"Given the reliance on witnesses and testimony, the operation of credible witness protection is a valuable indicator for the institutionalization of conditions conducive to truth-seeking. The South African TRC is notable in that it was the first truth commission to establish a witness protection program" (Lambert 2012: 217).

Therefore, the shortcomings of witness protection highlighted by the Goldstone Commission's operations resulted in the development of witness protection measures that were more conducive to truth-seeking. The Unity Act required the TRC to make recommendations for a witness protection program and ensure that the identity of vulnerable witnesses remained concealed (van Zyl, 1999). The conscious recognition of the centrality of institutionalization to the success of transitional justice and the actual operation of the South African TRC influenced the adoption and design of several truth commissions elsewhere in the world (Lambert, 2020).

\section{The Aftermath: Reconciliation and Nation-Building in Contemporary South Africa}

Twenty-seven years into democracy and the $22^{\text {nd }}$ year after the TRC report was submitted to South Africa's then President, Nelson Mandela, poverty, inequality, unemployment, and racism are still pervasive. South Africa's response to nation-building, aptly adopted through the Rainbow Nation ideology, was primarily associated with the chairpersons of the TRC, Bishop Desmond Tutu and Nelson Mandela. In Tutu's case, he believed in the interconnectedness of people from different traditions and racial groups. He used rainbow colours to evoke the significance of racial and cultural diversity in the country (Tutu, 2006; Evans, 2010; Palmer, 2016, Motlhoki, 2017). In Mandela's case, Evans (2010) reasons that three televised media events primarily enhanced the new nationalism that swept across South Africa. These events include Mandela's release from prison, his inauguration as the country's first democratically elected president, and the opening ceremony and the final game of the Rugby World Cup of 1995. The broadcasts were not only successful in creating an appearance of unity and stability, they most likely also generated increased support for the South African transition (Carlin, 2008; Evans, 2010). 
Despite a commitment to non-racialism in the South African Constitution and the emphasis of the Rainbow Nation ideology on multiculturalism, scholars criticize the ideology for being a barrier to structural inequality in South Africa (Gachago \& Ngoasheng, 2016), while others argue that racism continues to thrive in the country. A section of the white population uses a general culture of victimhood expressed in the so-called 'white genocide' rhetoric promoted by Afrikaner nationalist group Afriforum (Mncube, 2019).

Several interventions in postapartheid South Africa promoted the concerted effort to create a new national identity that rested on recognizing bonds of solidarity across racial boundaries (Guelke, 1999; Carlin, 2008) and the hope embodied by Mandela's presidency. For example, the TRC set a transformative agenda visible in the country's policy regime in the early stages of democracy. The emphasis on participatory governance in postapartheid South Africa has been linked to substantive innovations in public participation. One such innovation included a set of requirements for public involvement in various decision-making processes similar to those in Argentina, Brazil and Mexico (Barichievy et al., 2005; Booysen, 2009; Piper \& Nadvi, 2010). The participatory governance approach in several sectors of society, such as education, fostered trust in the government (Matebesi, 2020).

Today, novel insights into the social and political conditions of South Africa indicate that memories of past suffering bring pain and anger (Motlhoki, 2017; see also Molope's contribution to this volume). Despite the progressive proclamations in the 1994 Constitution, the problems at the centre of racial exclusion and marginalization in South Africa have become entrenched in governance institutions. This has sparked a sporadic public confrontation between racial groups and protests by predominantly black communities. Again, there is doubt among many South Africans, whether the objectives and goals envisaged by the TRC and the Constitution will be met (Lues, 2014). There is huge disappointment in much of the black population, as Southall's assertion eloquently captures:

"Disappointment among the black population at the limits of the democratic settlement is mounting; community protests against perceived ANC arrogance have continued into the new era; and Ramaphosa's renewal of the ANC has yet to see the removal of $\mathrm{Zu}$ ma strongmen within key provinces, prompting questions of whether the party can really reform. Much depends on whether Ramaphosa's reformist agenda succeeds or falters. ... But if it fails, the prospects of deepening political polarisation, resulting in Zimbabwe-style authori- 
tarianism and political decay, will be worryingly increased" (Southall, 2018: 206).

\section{Conclusion}

This article has set out to understand the role of citizen participation and political trust in the context of transitional justice in South Africa. South Africa moved from a political system concerned with racial polarization and economic inequality to a nation concerned with truth and reconciliation. However, in the current political environment-based on patronage and lack of accountability, and dishonesty and corruption as political capital-fractious racial relations and hopelessness reign supreme. This situation poses a serious threat to the contribution made by the TRC in advancing constitutional democracy in South Africa.

The article argues that the interface between participation and political trust is significant in promoting or preventing the capacities to implement and sustain complex institutions that are supposed to engender a sustainable memory culture. The institutional memory and culture of oppression and hatred in South Africa call for the enhancement of structures that deal with the promotion of racial pluralism rather than further regulation or policies. Such an approach calls for renewed attention and action to embody a sustainable memory culture in contemporary South Africa.

\section{References}

Aiken, Nevin, T. (2016): The distributive dimension in transitional justice: Reassessing the South African Truth and Reconciliation Commission's ability to advance interracial reconciliation in South Africa. In: Journal of Contemporary African Studies, 34 (2), 190-202.

Arthur, D., Issifu, A., \& Marfo, S. (2015): An analysis of the influence of ubuntu principle on the South Africa peace building process. In: Journal of Global Peace and Conflict, 3 (2), 63-77.

Bain, K., \& Hicks, N. (1998): Building social capital and reaching out to excluded groups: The challenge of partnerships. Paper presented at CELAM meeting on The struggle against poverty towards the turn of the millennium. Washington, DC: CELAM.

Barichievy, K., Laurence, P., \& Parker, B. (2005): Assessing "participatory governance' in local government: A case-study of two South African cities. In: Politeia 24 (3), 370-393. 
Bell, C. (2009): The 'New Law' on transitional justice. In: K. LargeAmbos, JK, Large, \& M, Wierda (Eds.): On building a future on peace and justice: Studies on transitional justice, peace and development. New York: Springer, 105-126.

Booysen, S. (2009): Beyond the ballot and the brick: continuous dual repertoires in the politics of attaining service delivery in South Africa.?' In: McLennan, A. \& Munslow, B. (Eds.): The politics of service delivery. Johannesburg: Wits University Press, 104-136.

Bosire, L. K. (2006): Overpromised, underdelivered: transitional justice in Sub-saharan Africa. In: Sur, International Journal of Human Rights, 3 (5), 70-107.

Bowsher, J. (2020): The South African TRC as neoliberal reconciliation: Victim subjectivities and the synchronization of affects. In: Social \& Legal Studies, 29 (1), 41-64.

Bubenzer, O. (2014): Post-TRC Prosecutions in South Africa: Accountability for Political Crimes after the Truth and Reconciliation Commission's Amnesty Process. Leiden: Brill

Carlin, J. (2008): Playing the enemy: Nelson Mandela and the game that made a nation. New York: Penguin.

Charbonneau, B. \& Parent, G. (2013): Peacebuilding, memory and reconciliation: bridging top down and bottom up approaches. London: Routledge.

Christodoulidis, E. (2000): Truth and reconciliation as risks. In: Social \& Legal Studies, 9 (2), 179-204.

Department of Justice and Constitutional Development (2011): Restorative Justice: The Road to Healing. Pretoria: Department of Justice and Constitutional Development.

Dlamini, J. (2009): Native nostalgia. Auckland Park: Jacana.

Downes, D., Rock, P.E. \& McLaughlin, E. (2016): Understanding deviance: a guide to the sociology of crime and rule-breaking ( $7^{\text {th }}$ ed). Oxford: Oxford University Press.

Duckitt, J., \& Mphuthing, T. (1998): Political power and race relations in South Africa: African Attitudes before and after the transition. In: Political Psychology, 19 (4), 809-832.

Duggan, C. (2012): "Show me your impact": Evaluating Transitional Justice in contested spaces: In: Journal of Evaluation and Program Planning, 35 (1), 199205.

Evans, M. (2010): Mandela and the televised birth of the rainbow nation. In: National Identities, 12 (3), 309-326.

Gachago, D. \& Ngoasheng, A. (2016): South Africa's 'rainbow nation' is a myth students need to unlearn. In: The Conversation, October 19. Available at: https:/ /theconversation.com/south-africas-rainbow-nation-is-a-myth-that-students-need -to-unlearn-66872

Gibson, J. L. (2005): Truth to reconciliation: Lessons from South Africa. In: Journal of Conflict Resolution, 50 (3), 409-432. 
Gormley-Heenan, C. \& Devine, P. (2010): The 'us' in trust: Who trusts Northern Ireland's political institutions and actors? In: Government and opposition, 45(2), 143-165.

Government of South Africa (1992): Prevention of Public Violence and Intimidation Act, 1991. Pretoria: Government Printers.

Gready, P., \& Robins, S. (2020): Transitional Justice and Theories of Change: Towards evaluation as understanding. In: International Journal of Transitional Justice, 14 (2), 280-299.

Greenbaum, B. (2006): Evaluation of the 2005 Ex-Combatants' Dialogues. Johannesburg: Centre for the Study of Violence and Reconciliation.

Grover, L. (2019): Transitional Justice, International Law and the United Nations. In: Nordic Journal of International Law, 88 (3),1-39.

Guelke, A. (1999): South Africa in transition: The misunderstood miracle. London: IB Taurus.

Hamber, B. \& Kibble, S. (1999): From Truth to Transformation: South Africa's Truth and Reconciliation Commission. Briefing paper. London: Catholic Institute for International Relations.

Hamber, B. (2000): Repairing the irreparable: Dealing with double-binds of making reparations for crimes of the past. In: Ethnicity and Health, 5(3): 215-226.

Hardin, R. (2002): Trust and trustworthiness. New York: Russell Sage Foundation.

Hayner, P. (2011): Unspeakable Truths: Transitional Justice and the Challenge of Truth Commissions. Abingdon: Routledge.

Jakobsson, E. (2018): Transitional Justice - An analysis of restorative and retributive mechanisms in Sub-Saharan Africa. Unpublished Bachelor Thesis in Peace and Development Studies. Linnaeus University, Kalmar \& Växjö, Sweden. https://www.diva-portal.org/smash/get/diva2:1219578/FULLTEXT01.pdf

Joyce, P. ( 2006): Criminal Justice: An introduction to crime and the criminal justice system. USA: Willan Publishing.

Krishna, A., \& Shrader, E. (2000): Crosscultural measures of social capital: A tool and results from India and Panama. World Bank Working Paper No. 21. Washington DC: World Bank.

Kumagai, S., \& Lorio, F. (2020): Building Trust in Government through citizen engagement. Washington D.C: World Bank.

Kunnen, E. (2018): Transitional Justice and Reconciliation: A case-study of the underlying ideas, objectives and frames in South Africa. Unpublished BSc Thesis Communication, Technology and PolicyMasters dissertation. Wageningen: Wageningen University and Research. Wageningen, The Netherlands. Available at: https://edepot.wur.nl/456018.

Lambert, T. (2020): The Goldstone Commission in South Africa's transition: Linking gradual institutional change and information-gathering institutions. Unpublished Doctoral thesis. Ontario: University of Western Ontario.

Lambourne, W. (2009): Transitional Justice and Peacebuilding after mass violence. In: International Journal of Transitional Justice, 3 (1), 28-48. 
Laplante, L.J. (20132). Negotiating reparation rights: The participatory and symbolic quotients. In: Buffalo Human Rights Law Review, 19: 217-250.

Laplante. L.J. \& Rivera Holguin, M.R. (2006): The Peruvian Truth Commission's mental health reparations: Empowering survivors of political violence to impact public health policy. In: International Journal of Health and Human Rights, 9 (2), 136-163.

Lues, L. (2014): Citizen participation as a contributor to sustainable democracy in South Africa. In: International Review of Administrative Sciences, 80 (4), 789-807.

Matebesi, S.Z. (2017): Civil strife against local governance: Dynamics of community protests in South Africa. Toronto: Barbara Budrich.

McEvoy, K. (2008): Letting go of legalism: Developing a 'thicker' version of transitional justice. In: McEvoy, K. \& McGregor, L. (Eds.): Transitional justice from below. Oxford: Hart Publishing, 15-47.

Millar, G. \& Lecy, J. (2016): Mapping the nexus between transitional justice and peacebuilding. In: Journal of Intervention and State-building, 10 (3), 302-320.

Mncube, P. (2019): The rainbow nation is dead. News24, 23 May. https:/www.new s24.com/news24/columnists/guestcolumn/the-rainbow-nation-is-dead-20190523.

Moon, C (2009): Healing past violence: Traumatic assumptions and therapeutic interventions in war and reconciliation. In: Journal of Human Rights, 8 (1): 71-91.

Motlhoki, S.M. (2017): The effectiveness of the South African Truth and Reconciliation Commission in the context of the five pillars of transitional justice. Unpublished Masters dissertation thesis in Politics. Pretoria: University of South Africa. Available at: https://core.ac.uk/download/pdf/129899228.pdf.

Newham, G. (2015): Keeping the wolves at bay: Issues and concerns in establishing a witness protection programme in South Africa. Johannesburg: The Centre for the Study of Violence and Reconciliation.

Palmer, F. T. (2016): Racialism and representation in the Rainbow Nation. In: SAGE Open, October-December: 1-14.

Piper, L., \& L. Nadvi. L. (2010): Popular mobilization, party dominance and participatory governance in South Africa. In: Thompson, L. \& Tascott, C. (Eds.). Citizenship and social movements: perspectives from the global south London.: Zed Books, 212-238.

Putnam, R. (2000): Bowling alone: The collapse and revival of American community. New York: Simon and Schuster.

Ramsbotham, O., Woodhouse, T. \& Miall, H. (2011): Contemporary conflict resolution: The management and transformation of deadly conflicts ( $3^{\text {rd }}$ ed.). Cambridge: Polity Press.

Robins, S. (2017): Failing victims? The limits of transitional justice in addressing the needs of victims of violations. In: International Legal Discourse, 1, 41-58.

Rubli, S. (2012): Transitional justice: Justice by bureaucratic means? Swiss Peace Working Paper, 4/2012. Available at: https:/www.almendron.com/tribuna/wp-co ntent/uploads/2018/12/transitional-justice-justice-by-bureaucratic-means.pdf. 
Seils, P. (2017): The place of reconciliation in transitional justice. The International Center for Transitional Justice Briefing Paper. Available at. https://www.ictj.org/ sites/default/files/ICTJ-Briefing-Paper-Reconciliation-TJ-2017.pdf.

Selim, Y. (2014): The opportunities and challenges of participation in transitional justice: Examples from Nepal. In: Journal of International Development, 29 (8), 1123-1148.

Shaw, R. \& Waldorf, L. (2010): Introduction: Localizing transitional justice. In: Shaw, R. \& Waldorf, L (Eds.): Localizing transitional justice: Interventions and priorities after mass violence. Stanford: Stanford University Press, 3-26.

The Special Rapoteur (2017): Transitional justice in weakly institutionalized postconflict settings: report. 6th session of the Human Rights Council. https://undoc s.org/A/HRC/36/50.

Subotić, J. (2009): Hijacked justice: Dealing with the past in the Balkans. Ithaca and London: Cornell University Press.

Triponel, A. \& Pearson, S. (2010): What do you think should happen? Public participation in transitional justice. In: Pace International Law Review, 22 (1), 103-144.

Truth and Reconciliation Commission (1998): Findings and recommendations (vol. 5), Truth and Reconciliation Commission of South Africa Report. London: Macmillan.

Tutu, D. (2006): Public dialogue event, memory, narrative and forgiveness Conference: Reflecting on ten years of South Africa's Truth and Reconciliation Commission, Cape Town.

Van der Meer, T. (2017): Political trust and the "crisis of democracy", In: Oxford Research Encyclopedia of Politics. DOI: 10.1093/acrefore/9780190228637.013. 77.

Van der Merwe, H. \& Lamb, G. (2009): Transitional Justice and DDR: The Case of South Africa. Research Unit International Center for Transitional Justice. https:/ /www.ictj.org/sites/default/files/ICTJ-DDR-South-Africa-CaseStudy-2009-English .pdf.

Van Zyl, P. (1999): Dilemmas of transitional justice: The case of South Africa's Truth and Reconciliation Commission. In: Journal of International Affairs, 52 (2), 647-667.

Vora, J.A., \& Vora, E (2004): The effectiveness of South Africa's Truth and Reconciliation Commission: Perceptions of Xhosa, Afrikaner, and English South Africans. In: Journal of Black Studies, 34 (3), 301-322.

Walaza, N. (2003): Reconciliation with partial truths: An assessments of the dilemmas posed by the reconciliation process in South Africa. In: Smith College Studies in Social Work, 73 (2), 189-204.

Waterhouse, C. (2009): The good, the bad and the ugly: Moral agency and the role of victims in reparations programs. In: University of Pennsylvania Journal of International Economic Law 31 (1), 257-294.

Wilson, R. (2001): The Politics of Truth and Reconciliation in South Africa: Legitimizing the Post-Apartheid State. Cambridge: Cambridge University Press. 
